\title{
First report of Biscogniauxia mediterranea causing canker on Erica multiflora L. in Tunisia
}

\author{
Islem Yangui ${ }^{1,2} \cdot$ Meriem Zouaoui Boutiti $^{1} \cdot$ Chokri Messaoud $^{2} \cdot$ Mohamed Lahbib Ben Jamaa $^{1} \cdot$ Andrea Vannini $^{3}$. \\ Anna Maria Vettraino ${ }^{3}$
}

Received: 18 December 2018 / Accepted: 3 June 2019/Published online: 17 June 2019

(C) Società Italiana di Patologia Vegetale (S.I.Pa.V.) 2019

Keywords Erica multiflora $\cdot$ Biscogniauxia mediterranea $\cdot$ Pathogenicity $\cdot$ Canker

Erica multiflora is one of the most valuable plants in the Mediterranean region. It is widely used in medicine because of its effective antiviral properties. In 2017, symptoms of dieback of E. multiflora plants were noticed for the first time in the forest of Ain sarouia $\left(8^{\circ} 499^{\prime} \mathrm{N} 36^{\circ} 73^{\prime} \mathrm{E}\right)$, situated in the Northwest of Tunisia. Out of the examined plants, $40 \%$ exhibited almost total defoliation and multiple cankers of small sizes on branches. Moreover, some branches showed black perithecia containing ascospores which were unicellular, elliptical and 7-9 $\times 3-4 \mu \mathrm{m}$ in size. Twenty small pieces of infected tissues were surface-sterilized in alcohol (70\%), rinsed with sterile distilled water and then dried on filter paper. Each piece was transferred to potato dextrose agar (PDA) and incubated at $25^{\circ} \mathrm{C}$ in the dark. After 7 days, a collection of 15 isolates was obtained. Colonies were first white and then turned olivaceous with white aerial mycelium. The identification of the isolates was initially based on colony characteristics

Islem Yangui and Meriem Zouaoui Boutiti contributed equally to this work.

Islem Yangui

yanguiislam@gmail.com

1 Laboratory of Management and Valorization of Forest Resources, National Institute for Research on Rural Engineering, Water and Forestry, BP. N.2, 2080 Ariana, Tunisia

2 Department of Biology, Laboratory of Nanobiotechnology and Medicinal Plants, National Institute of Applied Science and Technology (INSAT), University of Carthage, BP 676, 8 1080, Tunis Cedex, Tunisia

3 Department for Innovation in Biological, Agro-food and Forest systems (DIBAF) - University of Tuscia, Viterbo, Italy
(Henriques et al. 2015) and was confirmed by sequencing the ITS, the EF-1- $\alpha$ and the $\beta$-tubulin genes for a representative isolate. BLAST searches of ITS (MH356285), EF-1- $\alpha$ (MK189173) and $\beta$-tubulin (MK210238) sequences showed $100 \%$ identity with the Biscogniauxia mediterranea strain MEAN 965 isolated from Quercus suber in Portugal (GenBank accession numbers are KM216757, KM216793 and KM267169) (Henriques et al. 2016). Pathogenicity tests were conducted on ten detached and healthy branches of E. multiflora plants, inoculated with mycelial plugs of the representative isolate and then placed in polyethylene boxes at $25{ }^{\circ} \mathrm{C}$ (Yan et al. 2011). Control branches received sterile agar plugs. After 30 days, necrotic lesions developed on all inoculated tissues. Control branches remained healthy. The pathogen was consistently re-isolated from the infected tissues. To our knowledge, this is the first report of canker disease caused by Biscogniauxia mediterranea on Erica multiflora in Tunisia.

\section{References}

Henriques J, Nóbrega F, Sousa E, Lima A (2015) Morphological and genetic diversity of Biscogniauxia mediterranea associated to Quercus suber in the Mediterranean Basin. Revista de Ciências Agrárias 38:166-175

Henriques J, Nóbrega F, Sousa E, Lima A (2016) Analysis of the genetic diversity and phylogenetic relationships of Biscogniauxia mediterranea isolates associated with cork oak. Phytoparasitica 44:19-34

Yan JY, Peng YL, Xie Y (2011) First report of grapevine trunk disease caused by Botryosphaeria obtusa in China. Plant Dis 95:616

Publisher's note Springer Nature remains neutral with regard to jurisdictional claims in published maps and institutional affiliations. 